Audrey Nicholls, ed.

The Arts and Jesuit Influence in the Era of Catholic Reform. Special issue of Studies:

An Irish Quarterly Review 104, no. 416 (Winter 2015/2016). Pp. 131.10 euros.

This special issue of Studies published ten papers originally given at a 2014 conference at the National Gallery of Ireland in conjunction with its painting exhibition, Passion and Persuasion: Images of Baroque Saints. It is always difficult for anthology editors to devise a general title for their volume that is comprehensive, self-explanatory, and accurate. In this regard Nicholls's title is not especially felicitous, specifically concerning the "Jesuit influence": readers should be advised that of the ten essays, seven have nothing to do with Jesuit art, spirituality, or influence, and of those that do, the essay (by John W. O'Malley, S.J.) takes up the matter only in its second half. Nonetheless, even specialists in Jesuit studies will find this collection, on the whole, worthwhile reading: the essays here contained are brief but almost all of them deliver much by way of new data and new insight, both those written by eminent veteran scholars as well as those by younger ones.

The first essay, "Counter Reformation Countenances: Catholic Art and Attitude from Caravaggio to Rubens" by John Gash covers an extremely broad range of topics (though chronologically narrowly focused) in just twelve pages. The essay defies summary in the space of a short review so I simply borrow his opening statement: "By Counter-Reformation countenances, I mean three things: the portraits [...] both of the leading figures in the movement and of some of the artists who enunciated Counter-Reformation dogma in paint or stone; the concrete face of that ideology in terms of the works of art produced to reinforce it; and the shifting contours of Catholic faith, as it navigated its responses to the Lutheran and Calvinist challenges" (373). In "Fellow Travellers: Caravaggio's Dublin The Taking of Christ and London Supper at Emmaus," Philip Cottrell enhances our understanding of two of Caravaggio's most accomplished paintings by considering "the stylistic, compositional and iconographical implications of the possibility that these works were intended as pendants" (388). Simone Mancini's "Caravaggio's Technique: The Taking of ChristAdvanced Research into Practice and Process" communicates the results of the most recent laboratory analysis of the material substance of that Caravaggio masterpiece, especially the revelations of his working habits made possible by infra-red reflectography. These results are invaluable for all future debate over the attribution of any work purported to be by Caravaggio. Stephen Boyd's "El Greco's El Espolio: Scriptural, Devotional and Liturgical Contexts" moves us away from seventeenth-century Rome to sixteenth-century Toledo, 
as the author analyzes this idiosyncratic and richly textured depiction (still in situ in the Toledo cathedral) of the passion scene of the disrobing of Christ (which turns out to be more a depiction of the Triumphant Messiah).

Back in seventeenth-century Rome, one of the most famous group canonizations of the early modern period occurred in 1622: in that year five heroically virtuous beati were all together declared sancti-Isidore the Farmer, Ignatius of Loyola, Francis Xavier, Teresa of Ávila, and Philip Neri. Marta Bustillo's “Images of Saint Isidro the Farmer" focuses on the least known member of that group, Isidore, "a humble farmhand renowned for his Christian piety" (423) who died in Madrid circa 1172. Bustillo's aim is to demonstrate how his cult "played an important role in defining the Christian identity of the Spanish capital" while it also "provided Madrid, a small town with no cathedral and no aristocratic roots, with a pedigree as an ancient place" (423). In "The Holy Grandmother and 'the Fleshly Trinity," Catherine Lawless focuses on the legendary figure of St. Anne (mother of the Virgin Mary) with an illuminating exploration of her many-faceted cult and "polyvalent" images. Among the many things to be learned from this essay is the fact that the oft-depicted scene of Anne teaching the child Mary to read had all to do with the coming of the Logos, Jesus Christ, and really little to do with female literacy.

In "Bernini (1598-1680): Sculpting Sainthood," Genevieve Warwick considers Bernini's much beloved Ecstasy of Saint Teresa from multiple points of view, but above all leading us through a detailed observation of the work itself-its materials, its composition, its sources, and its symbolism (e.g., Eucharistic), with special emphasis on Bernini's ingenuous lighting effects to which the statue owes so much of its aesthetic appeal and symbolic charge. Regarding Teresa's pose, Warwick is correct that it "has not clear antecedent in the history of her visual representation" (452) but neglects to observe that in fact the composition of this sculptural group is clearly-and provocatively-borrowed from the popular, early modern representations of Cupid and Venus or Danaë and the Shower of Gold, as contemporary viewers would have noticed.

With the last three essays of this collection we enter explicitly Jesuit territory. In her "Memento mori' in Baroque Rome," Corinna Ricasoli reconstructs the seventeenth-century remaking of the ancient iconographic motifs deriving from the ars moriendi tradition, the representations of death and dying. The key textual source of this visual revival was Jesuit Robert Bellarmine and his influential treatise, De arte bene moriendi (1620). The penultimate essay is Gauvin Bailey's “The Iconography of Jesuit Saints in the Church of San Pedro in Lima," a carefully detailed and well-informed inventory of the interior decoration of the Jesuit church in Peru built in 1623-38. For those who are acquainted 
with traditional Jesuit iconography, the church, however, offers no surprises or novelties or idiosyncrasies: although of exquisite beauty, the iconography all seems rather predictable. As for the final essay (which comes with no footnotes), "The Jesuits and the Arts in the Tridentine Era" by O'Malley, I have already mentioned that only one half concerns the Jesuits, as announced in its title. The other (first) half of the essay instead focuses on the Council of Trent's important but widely misunderstood decree on sacred images. This part of the essay essentially repeats in briefer form his longer, carefully annotated essay in the 2013 volume edited by Marcia Hall and Tracy Cooper, The Sensuous in the Counter-Reformation Church (Cambridge: Cambridge University Press, 2013). As I remarked in my review of the Hall-Cooper book (http://www.caareviews. org/reviews/2145), O'Malley's essay should be obligatory reading for anyone working on any aspect of the Counter-Reformation that intersects with the visual arts in any way.

\section{Franco Mormando}

Boston College

mormando@bc.edu

DOI 10.1163/22141332-00304009-13 